\title{
Hypoglycemic Effect of Kalanchoe pinnata (Lam) Pers. Leaf Extract
}

\author{
Ana L. Agüero-Hernández ${ }^{1, *}$, Catalina Rosales-López', Cristina Herrera², Andrés Vargas-Picado ${ }^{3}$, Rodrigo \\ Muñoz $^{3}$ and Ana Abdelnour-Esquivel ${ }^{1}$
}

Ana L. Agüero-Hernández ${ }^{1, *}$, Catalina Rosales-López ${ }^{1}$, Cristina Herrera' ${ }^{2}$, Andrés Vargas-Picado ${ }^{3}$, Rodrigo Muñoz and Ana Abdelnour-Esquivel ${ }^{1}$

${ }^{1}$ Centro de Investigación en Biotecnología (CIB), del Instituto Tecnológico de Costa Rica, Cartago, COSTA RICA

2Instituto de Investigaciones Farmacéuticas (INIFAR), Facultad de Farmacia, Universidad de Costa Rica, San José, COSTA RICA.

3Centro Nacional de Innovaciones

Biotecnológicas (CENIBiot), San José, COSTA RICA.

\section{Correspondence}

\section{Ana L. Agüero-Hernández}

Centro de Investigación en Biotecnología

(CIB), del Instituto Tecnológico de Costa

Rica, Cartago, COSTA RICA

E-mail: anaguero@itcr.ac.cr

History

- Submission Date: 12-11-2019;

- Review completed: 02-12-2019;

- Accepted Date: 06-01-2020.

DOI : 10.5530/pj.2020.12.84

Article Available online

http://www.phcogj.com/v12/i3

\section{Copyright}

(C) 2020 Phcogj.Com. This is an openaccess article distributed under the terms of the Creative Commons Attribution 4.0 International license.

\begin{abstract} of this Crassulaceae as a home remedy.

\section{INTRODUCTION}

Diabetes Mellitus (DM) is a global health problem. It is the most common of the endocrine disorders and is characterized by chronic hyperglycemia caused by a relative or absolute lack of insulin secretion or insulin activity. According to the World Health Organization (2016), ${ }^{1}$ the diabetic population is projected to increase to 300 million or more by the year 2025. In Costa Rica, 8743 new cases of Diabetes mellitus were reported in 2014, representing a rate of increase of 183.17 cases per 100000 inhabitants. $^{2}$ In the same year, there were 720 deaths from this disease, representing 15.08 deaths per 100000 inhabitants, primarily among women older than 75 years of age. ${ }^{3}$
\end{abstract}

Introduction: Kalanchoe pinnata (Lam) Pers (Crasulaceae) is a succulent ornamental plant. In Costa Rica, the leaves are used as a coadjuvant treatment for Diabetes Mellitus based on traditional knowledge of natural remedies. Moreover, there are some studies mentioning its use for Diabetes Mellitus as medicinal plant in several countries. This research aimed to demonstrate the antidiabetic properties of hydroalcoholic extracts of $K$. pinnata leaves through phytochemical screening, alpha amylase inhibition and rodent models. Methods: Crude extracts of $K$. pinnata leaves were prepared by infusion and decoction using water:ethanol (70:30) as a solvent. The extracts prepared by decoction (LAED, Iyophilized-water:ethanoldecoction) and by infusion (LAEI, lyophilized-water:ethanol-infusion) were analyzed by FolinCiocalteu, HPLC and capacity of inhibition of $\alpha$-amylase activity. To determine hypoglycemic activity in rats, extracts were administered orally at doses of 250,500 and $750 \mathrm{mg} / \mathrm{Kg}$ and blood sugar levels were monitored over a four hours period using a glucometer. Results: A significant reduction $(p<0.05)$ in blood glucose was observed after one hour in rats treated with $500 \mathrm{mg} / \mathrm{Kg}$ of LAED extract. Treatment with $750 \mathrm{mg} / \mathrm{Kg}$ LAEI induced a statistically significant reduction in blood sugar at 90, 180 and $240 \mathrm{~min}$, showing that the glucose-lowering effect of this extract was greater at a higher concentration. Conclusions: This study confirmed the hypoglycemic effect of $K$. pinnata extracts in the acute phase in rats and supports the use

Key Words: Antidiabetic activity, Diabetic, Extract, Kalanchoe pinnata.

The recommended treatment for diabetes includes oral medications or subcutaneous insulin injections, as well as diet modification and exercise. However, some of the medications can cause secondary effects in patients. Modern synthetic prescription medications and insulin for effective treatment of diabetes are scarce, especially in rural areas, since they are expensive and have important adverse effects. There is not ideal medication for the treatment of Diabetes mellitus that can control blood sugar without secondary effects such as hypoglycemia and weight gain, and also reduce cardiovascular morbimortality and maintain the integrity and normal functioning of pancreatic cells. Development of complementary and alternative approaches to diabetes management, such as the isolation of phytochemicals with antihyperglycemic activity, is imperative. For this reason, many patients resort to home remedies or medicinal plants for diabetes treatment or to complement prescribed medications. ${ }^{4}$

Medicinal plants have been known for thousands of years and are appreciated as rich sources of therapeutic agents for the prevention of disease and other ailments. ${ }^{5}$ Kalanchoe pinnata (Lam) Pers. (Synonym Bryophyllum pinnatum) is a succulent plant native to Madagascar and found in South America, India, and the Caribbean. ${ }^{6}$ Leaves of this plant are consumed raw or prepared as infusions or decoctions as alternative medicine for diabetes. ${ }^{7,8}$ Other therapeutic properties attributed to this plant include antibacterial activity against Staphylococcus, E. coli, Shigella, Bacillus and Pseudomonas, ${ }^{9}$ and anticancer, ${ }^{10}$ antiparasitic, ${ }^{11}$ antiallergic, and antiinflammatory properties. ${ }^{12}$ This research aimed to demonstrate the antidiabetic properties of hydroalcoholic extracts of $K$. pinnata leaves through phytochemical screening, alpha amylase inhibition and rodent models.

\section{MATERIALS AND METHODS}

\section{Plant material}

Kalanchoe pinnata (Lam) Pers. plants were collected

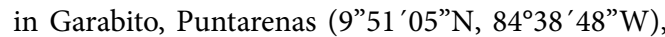
Costa Rica. Permits for collection and bioprospection were obtained from the National Commision for Biodiversity CONAGEBIO (R-CM-ITCR-0014- 
2018-OT). The collected plant material was identified at the National Herbarium of the National Museum of Costa Rica (DHN: 060-2017). Plants were transferred to a greenhouse for leaf propagation.

\section{Preparation of extracts}

Leaves were washed with antibacterial soap and water and dried by lyophilization (L) $\left(-20^{\circ} \mathrm{C}, 50\right.$ bar for $\left.14 \mathrm{~h}\right)$. After drying, leaves were pulverized using a laboratory knife mill (IKA ${ }^{\star}$, Germany) and stored in the dark.

Extracts of the dried leaf powder were prepared by infusion (I) or decoction (D) at a ratio of 1:10 (w/v) using water:ethanol (70:30) (AE, acronym in Spanish) as the extraction solvent. Each sample was extracted five times. The extracts were centrifuged, lyophilized and protected from light.

\section{Phytochemical screening}

Total polyphenols were quantified using the Folin-Ciocalteu method. ${ }^{13}$ The phenolic compounds kaempferitrin ${ }^{\circ}$ and kaempferol ${ }^{\circ}$ were quantified by HPLC (High Performance Liquid Chromatography), Agilent Technologies. Detection was achieved at $280 \mathrm{~nm}$ at $30^{\circ} \mathrm{C}$ with a flow rate of $0.3 \mathrm{~mL} / \mathrm{min}$, using $5 \mu \mathrm{L}$ of extract. Phase A consisted of 99.9\% water and $0.1 \%$ formic acid. Phase B was 50\% methanol and 50\% acetonitrile. The gradient phase was $88 \% \mathrm{~A}$ and $12 \% \mathrm{~B}$, and the final phase was $35 \% \mathrm{~A}$ and $45 \% \mathrm{~B}$.

\section{A-amylase inhibition assay}

The inhibitory effect of the extracts on the enzyme $\alpha$-amylase was determined using the EnzChek ${ }^{\circ}$ Ultra Amylase Assay Kit (Thermo Fisher Scientific E33651) with some modifications. Briefly, different concentrations of the extracts were incubated with $2 \mathrm{mU}$ of Bacillus sp. a-amylase (A-6380-Sigma), at room temperature for $30 \mathrm{~min}$. Incubation of $\alpha$-amylase without extracts were used as positive control. After incubation of the enzyme and the extracts, $10 \mathrm{ug}$ of the DQ starch substrate were added to the mixture and incubated for $30 \mathrm{~min}$ at room temperature. The fluorescence was measured in the Synergy ${ }^{\circ}$ plate reader adjusted for absorption at $480 / 20 \mathrm{~nm}$ and emission at 528/20 $\mathrm{nm}$.

\section{Hypoglycemic activity: Oral starch tolerance model Drugs}

Glibenclamide 5 mg (Lisan ${ }^{\circledR}$ Laboratories, San José, Costa Rica). Two tablets were dissolved in $20 \mathrm{ml}$ of distilled water for oral administration at a dose of $7.5 \mathrm{mg} / \mathrm{Kg}$.

\section{Animals}

Male Sprague-Dawley rats weighing between 180 and $220 \mathrm{~g}$ were obtained from the Biological Assays Laboratory Bioterium of the University of Costa Rica. The experimental protocol was approved by the University Bioethics Committee (CICUA-053-17). Rats were maintained under standard conditions of temperature $22 \pm 2{ }^{\circ} \mathrm{C}$, with light/dark cycles of $12 \mathrm{~h}$ and food and water ad libitum.

\section{Hypoglycemic activity: Oral starch tolerance model}

Rats were subjected to a $12 \mathrm{~h}$ fasting period prior to oral starch tolerance testing. Each rat was weighed to determine the amount of extract to be administered. Groups of 7 animals received the following treatments: hydroalcoholic extracts LAED (lyophilized-water:ethanoldecoction) and LAEI (lyophilized-water:ethanol-infusion) at 250, 500 and $750 \mathrm{mg} / \mathrm{Kg}$ body weight dissolved in water, water (negative control) and glibenclamide (positive control). Thirty minutes after treatments were applied; each rat was fed $2 \mathrm{~g}$ of starch per $\mathrm{kg}$ of body weight. All treatments were administered orally. Blood glucose was measured in fasting rats (time 0 ) and 30 minutes after treatments were administered (time 1). Further glucose measurements were made 30, 60, 90, 120, 180 and $240 \mathrm{~min}$ after starch ingestion. Blood samples were obtained by scratching the tip of the tail using a scalpel. Blood glucose levels were quantified with an Accu Chek Performa ${ }^{\circ}$ glucometer. The change ratios of blood glucose levels were calculated for each animal using the following formula: $100+100 \times$ (postdrug blood glucose level - predrug blood glucose level) / (predrug blood glucose level).

\section{Statistical analysis}

Treatments in the in vivo test (LAEI and LAED extracts at $750 \mathrm{mg} / \mathrm{Kg}$, $500 \mathrm{mg} / \mathrm{Kg}$ and $250 \mathrm{mg} / \mathrm{Kg}$ ) were compared at each sampling time. Results were analyzed by One-way ANOVA and the Fisher test. A value of $\mathrm{p}<0.05$ was considered statistically significant.

\section{RESULTS}

\section{Phytochemical screening}

Lyophilization conserved the appearance and color and the concentration of chemical compounds of interest. The LAEI and LAED fractions contained high concentrations of polyphenols $(1.467 \mathrm{mg}$ and $0.898 \mathrm{mg}$ EQ of gallic acid $/ \mathrm{mL}$ ) and flavonoids (0.08 and $0.05 \mathrm{mg}$ EQ quercetin/mL), respectively, and identify Kempherol and Kapheritrin by HPLC. This information is consistent with that reported by Tadera $e t$ al, (2006), ${ }^{14}$ who found that naringenin, kaempferol, luteolin, myricetin and quercitin were potential inhibitors of porcine alpha-amylase. The presence of inhibitory compounds in the LAEI and LAED extracts suggests their potential as diabetes treatments.

\section{A-amylase inhibition}

Inhibition of enzyme activity by LAED and LAEI extracts was greater than $90 \%$ (97\% and $92.7 \%$, respectively) at an extract concentration of $100 \mu \mathrm{g} / \mathrm{mL}$ (Figure 1).

\section{Hypoglycemic activity}

Treatment with LAED $500 \mathrm{mg} / \mathrm{Kg}$ resulted in significantly lower $(\mathrm{p}<0.05)$ blood glucose levels than in negative control (water) treatments 60, 90, 120 and $180 \mathrm{~min}$ after starch ingestion. Moreover, the lowest $(250 \mathrm{mg} / \mathrm{Kg})$ and highest $(750 \mathrm{mg} / \mathrm{Kg})$ concentrations of LAED extracts induced a reduction in glucose levels 180 and 240 minutes after starch ingestion, respectively (Figure 2A).

On the other hand, the effect of LAEI $250 \mathrm{mg} / \mathrm{Kg}$ was significantly different from negative control at 90 minutes, after which the effect was similar to water. However, at $750 \mathrm{mg} / \mathrm{Kg}$, blood glucose was significantly lower at 90, 180 and 240 minutes, showing that at a higher concentration the hypoglycemic effect was greater (Figure $2 \mathrm{~B}$ ).

\section{DISCUSSION/CONCLUSIONS}

Inhibition of the intestinal enzyme a-amylase may represent an important therapeutic approach for the treatment of Type 2 diabetes. Inhibition of this enzyme impedes carbohydrate digestion and slows glucose absorption, thereby reducing the increase in postprandial glucose in the plasma. ${ }^{14,15}$ Some phenolic acids and flavonoids known for their antioxidant properties have been associated with enzyme inhibition and may be candidates for control of starch digestion and postprandial glycemia. ${ }^{15,16}$

Blood sugar was significantly lower in rats treated with glibenclamide $(7.5 \mathrm{mg} / \mathrm{Kg}$ ) than in rats treated with extracts or water (negative control) at all evaluation times (from 30 to $240 \mathrm{~min}$ ). This response was expected, as glibenclamide is a commercial medicine used for diabetes control. It would be interesting to determine the effect of the natural 


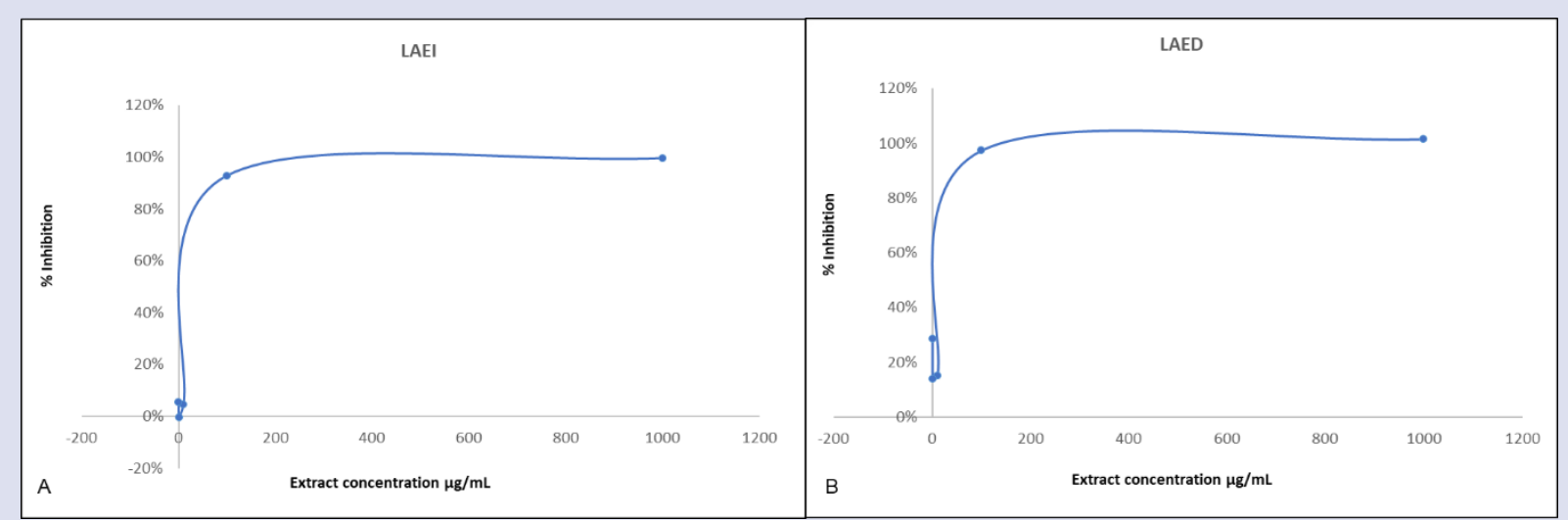

Figure 1: Percent inhibition of a-amylase by extracts of Kalanchoe pinnata LAED (lyophilized-water:ethanol-decoction) and LAEI (lyophlized-water:ethanol-infusion, acronym in Spanish).

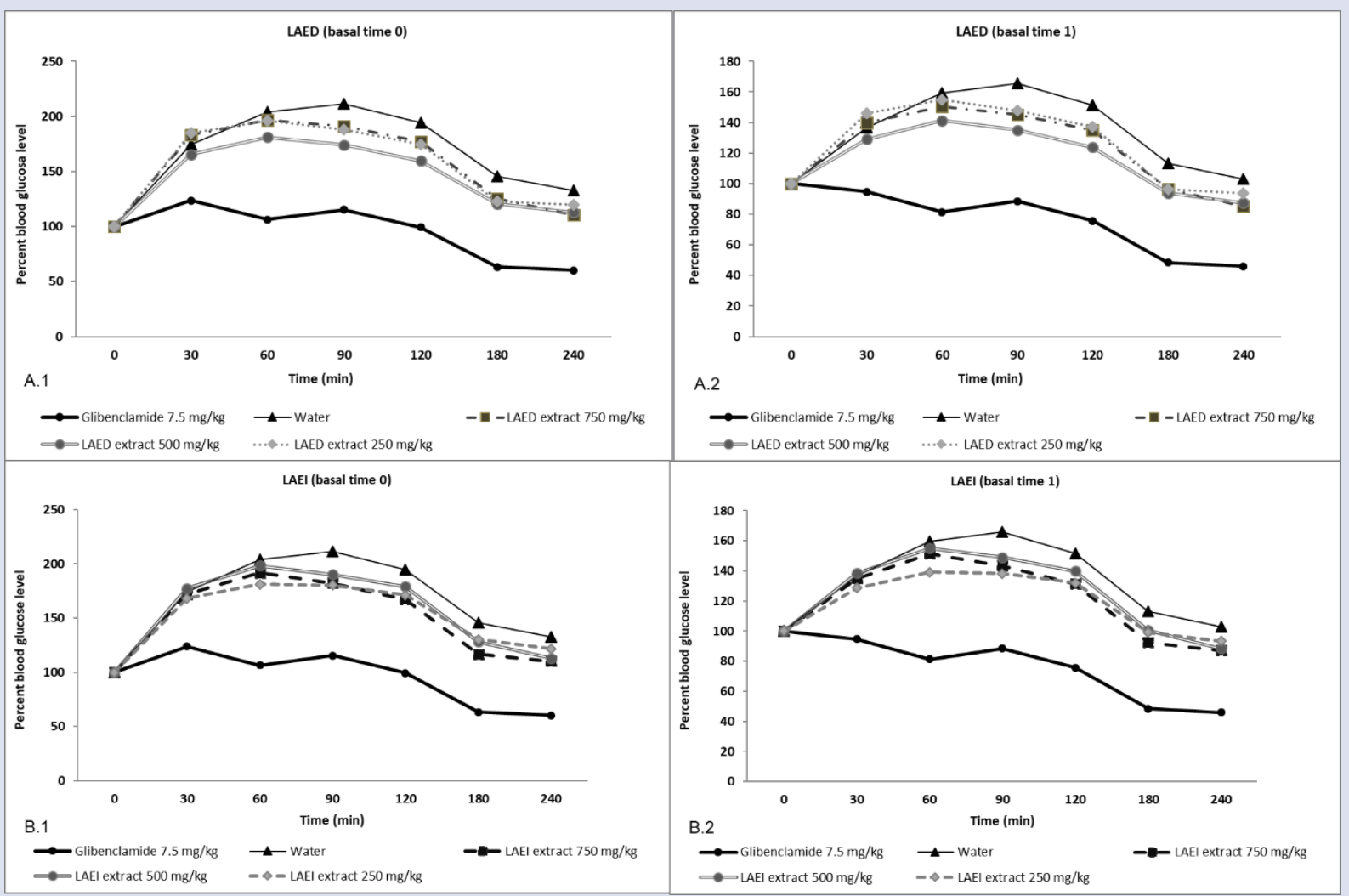

Figure 2: Hipoglycemic activity of hydroalcoholic extracts of $K$. pinnata leaves at different doses in rats $(n=7)$. (A) Percentage reduction of blood glucose measured at time 0 (fasting glucose) and after administering the extract (basal time 1) of LAED. (B) Percentage reduction of blood glucose measured at time 0 (fasting glucose) and after administering the extract (basal time 1) of LAEI.

extract administered jointly with glibenclamide in order to evaluate the coadjuvant effect of this plant species. ${ }^{17}$

Although the effect of the extracts did not surpass that of glibenclamide, blood sugar was reduced at most of the extract concentrations and evaluation times (Figure 2).

Ojewole $(2005)^{7}$ obtained similar results with aqueous extracts of $B$. pinnatum at $400 \mathrm{mg} / \mathrm{Kg}$. Blood glucose levels were significantly lower relative to controls one and two hours after administration of the extracts, with a peak reduction at two and four hours. Ogbonnia et al $(2008)^{18}$, using hydroalcoholic mixtures of extracts of $B$. pinnatum and T. africana (500 $\mathrm{mg} / \mathrm{Kg}$ body weight), reported lowered blood glucose levels in diabetic rats after 120 minutes. Results of this study provide evidence of the hypoglycemic effect of $K$. pinnata in traditional home preparations of infusions or decoctions and support its possible use as a natural coadjuvant for enhanced diabetes control. Therefore, it would be interesting to evaluate the antihyperglycemic activity of $K$. pinnata in diabetic animals.

We choose LAEI and LAED fractions contained high concentrations of polyphenols $(1.467 \mathrm{mg}$ and $0.898 \mathrm{mg}$ EQ of gallic acid $/ \mathrm{mL})$ and flavonoids $(0.08$ and $0.05 \mathrm{mg}$ EQ quercetin $/ \mathrm{mL}$ ). In addition, was greater than $90 \%$ in a-Amylase Inhibition.

This study confirmed the hypoglycemic effect of K. pinnata in the acute phase. The effects of the extracts on postprandial glucose in plasma were evaluated during a four hours period following starch ingestion. 
Although the extracts did not elicit the same response as the commercial drug glibenclamide, the extracts LAED $(500 \mathrm{mg} / \mathrm{Kg})$ and LAEI (750 $\mathrm{mg} / \mathrm{Kg}$ ) induced a positive response in the reduction of blood glucose levels after starch ingestion. The LAED $(500 \mathrm{mg} / \mathrm{Kg})$ extract showed a more constant glucose reduction over time.

These results show the enormous pharmacological potential of $K$. pinnata and the importance of further research. It will be important to evaluate the effect of these extracts administered jointly with glibenclamide to determine their function as coadjuvants to potentiate or enhance the response to prescription medications.

\section{ACKNOWLEDGEMENTS}

This research was supported by the Vice Rectorate for Research of the Instituto Tecnológico de Costa Rica through Grant 1510035.

\section{ABBREVIATION}

CENIBiot: Centro Nacional de Innovaciones Biotecnológicas; CIB: Centro de Investigación en Biotecnología; INIFAR: Instituto de Investigaciones Farmacéuticas; ITCR or TEC: Instituto Tecnológico de Costa Rica; LAED: Lyophilized-water:ethanol-decoction; LAEI: Llyophilized-water:ethanol-infusion.

\section{REFERENCES}

1. Organización Mundial de la Salud. Organización Mundial de la Salud. Obtenido de 7 de abril de 2016- Día Mundial de la Salud: diabetes: http://www.who.int/ campaigns/world-health-day/2016/event/es/

2. Ministerio de Salud de Costa Rica. Boletín Estadístico de Enfermedades de Declaración Obligatoria en Costa Rica del año 2015. San José, Costa Rica. 2015

3. Ministerio de Salud de Costa Rica. Boletín Estadístico de Mortalidad por Enfermedades de Declaración Obligatoria en Costa Rica del año 2014. San José, Costa Rica: Ministerio de Salud. 2014.

4. Menon N, Sparks J, Omoruyi F. Hypoglycemic and hypocholesterolemic activities of the aqueous preparation of Kalanchoe pinnata leaves in streptozotocininduced diabetic rats. Asian Pacific Journal of Tropical Biomedicine. 2015;5(1):39.

5. Joseph B, Priya RM. Phytochemical and biopharmaceutical aspects of Psidium guajava (L.) essential oil: A review. Res J Med Plants. 2011;5432-442.
6. Menon N, Sparks J, Omoruyi FO. Oxidative stress parameters and erythrocyte membrane adenosine triphosphatase activities in streptozotocin-induced diabetic rats administered aqueous preparation of Kalanchoe pinnata leaves. Pharmacognosy Research. 2016;8(2):85.

7. Ojewole JA. Antinociceptive, anti-inflammatory and antidiabetic effects of Bryophyllum pinnatum (Crassulaceae) leaf aqueous extract. Journal of Ethnopharmacology. 2005;99(1):1319.

8. Prasad AK, Kumar S, Iyer SV, Sudani RJ, Vaidya SK. Pharmacognostical, phytochemical and pharmacological review on Bryophyllum pinnata. International Journal of Pharmaceutical \& Biological Archives. 2012;3(3):423-33.

9. Joseph B, Priya RM, Helen PM, Sujatha S. Bio-active compounds in essential oil and its effects of antimicrobial, cytotoxic activity from the Psidium guajava (L.) leaf. J Adv Biotechnol. 2010;9:10-4.

10. Supratman U, Fujita T, Akiyama K, Hayashi H, Murakami A, Sakai H, et al Anti-tumor Promoting Activity of Bufadienolides from Kalanchoe pinnata and $K$. daigremontianax butiflora. Bioscience, Biotechnology and Biochemistry. 2001;65(4):947-9.

11. Chenniappan K, Kadarkarai M. In vitro antimalarial activity of traditionally used Western Ghats plants from India and their interactions with chloroquine against chloroquine-resistant Plasmodium falciparum. Parasitology Research. 2010:1351-64.

12. Lans CA. Ethnomedicines Used in Trinidad and Tobago for Urinary Problems and Diabetes Mellitus. Journal of Ethnobiology and Ethnomedicine. 2006;2(52):4555.

13. Waterhouse AL. Determination of total phenolic compounds. Current Protocols in Food Analytical Chemistry. 2002.I1.1.1-I1.1.8.

14. Tadera K, Minami Takamatsu K, Matsuoka T. Inhibition of $\alpha$-glucosidase and $\alpha$-amylase by flavonoids. Journal of Nutritional Science and Vitaminology. 2006;52(2):149-53.

15. Ali Asgar MD. Anti-diabetic potential of phenolic compounds: A review. International Journal of Food Properties. 2013;16(1):91-103.

16. Lo Piparo E, Scheib H, Frei N, Williamson G, Grigorov M, Chou CJ. Flavonoids for controlling starch digestion: structural requirements for inhibiting human $\alpha$-amylase. Journal of Medicinal Chemistry. 2008;51(12):3555-61.

17. Aransiola E, Daramola M, Iwalewa E, Seluwa A, Olufowobi O. Anti-Diabetic Effect of Bryophyllum pinnatum Leaves. International Journal of Biological, Biomolecular, Agricultural, Food and Biotechnological Engineering. 2014;8(1):8993.

18. Ogbonnia S, Odimegwu J, Enwuru V. Evaluation of hypoglycaemic and hypolipidaemic effects of aqueous ethanolic extracts of Treculia africana Decne. and Bryophyllum pinnatum Lam. and their mixture on streptozotocin (STZ) induced diabetic rats. African Journal of Biotechnology. 2008;7(15):25359 .

\section{GRAPHICAL ABSTRACT}

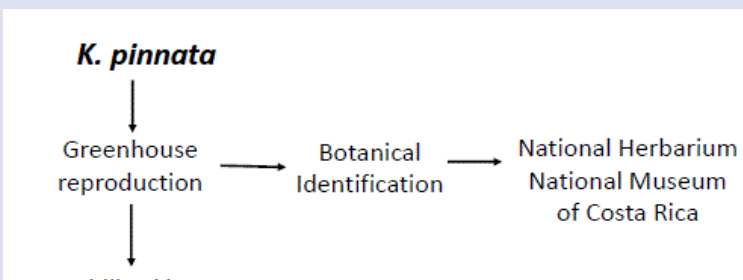

Lyophilized leaves
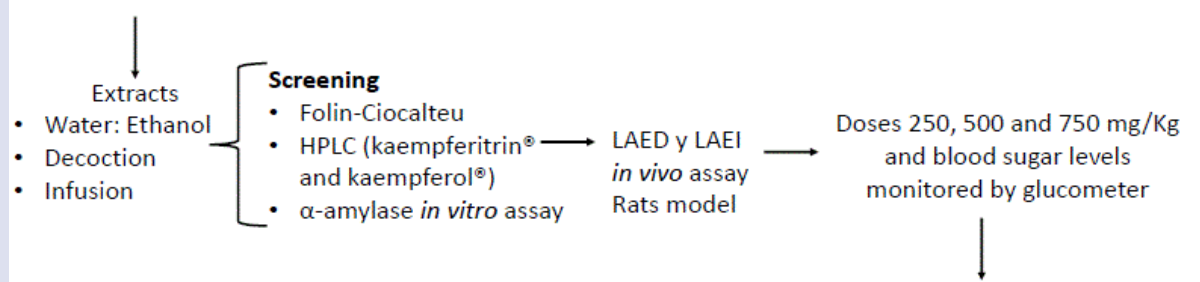

Significant reduction $(p<0.05)$ in blood glucose:

- $500 \mathrm{mg} / \mathrm{Kg}$ LAED extract after 1 hour.

- $750 \mathrm{mg} / \mathrm{Kg}$ LAEI at 90,180 and $240 \mathrm{~min}$. 


\section{ABOUT AUTHORS

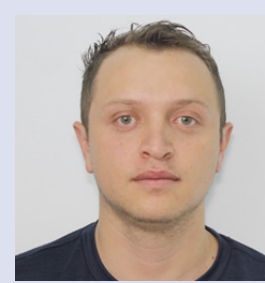 \\ Skills and Expertise \\ - Chormatography \\ - Material characterization \\ - Extraction \\ - HPLC \\ - Chemical analysis \\ - Spectroscopy}

Muñoz, Rodrigo currently works at National Center of innovatins biotechnology. Rodrigo does research in phytochemsitry, Industrial Chemistry and mass spectrometry

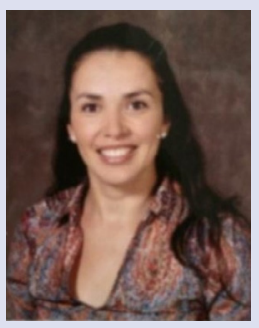

Rosales-López, Catalina, Biotechnology Engineer, MSc. Biotechnology, Natural Products area, works at the Tecnológico de Costa Rica, and Biotechnology Research Center. Experience in phytochemical and bioprocess research, and in vivo and in vitro tests of bioactive compounds.

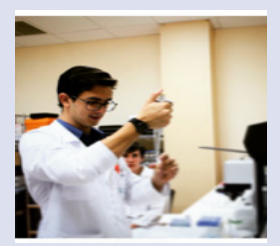

Vargas Picado, Andrés. Biotechnology Engineer. Research in the different areas of plant biotechnology and phytochemistry. Actually, works in a microbiological analysis company for biomedical industries. Experience in identification and characterization of bioactive compounds (management of mass spectrometry and HPLC for elucidation of molecules derived from plants, analysis and spectrophotometric determination of compounds such as tannins, polyphenols, flavonoids, anthocyanins, among others).

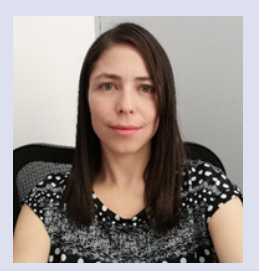

Herrera-Arias, Cristina. Academic Degree and Professional Doctorate in Pharmacy, University of Costa Rica, 2007; Master in Biomedical Sciences with Emphasis in Biochemistry and Cellular Physiology, University of Costa Rica, 2012; Doctorate in Sciences, University of Costa Rica, 2018. Works since 2007 in the Department of Pharmacology, Toxicology and Drug Dependence, School of Pharmacy, University of Costa Rica. Has 20 publications in the area of Pharmacology and Toxinology, specifically in the study of biological activities of natural products and the mechanism of action of metalloproteinases.

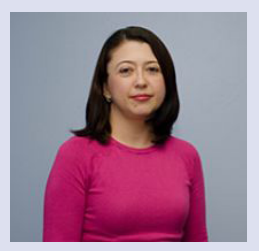

Agüero-Hernández, Ana Laura. Biotechnology Engineer, Master in Occupational Health and Environmental Hygiene. Works since 2014 at Instituto Tecnológico de Costa Rica, Biotechnology Research Center. Experience in vivo and in vitro tests of bioactive compounds of plants.

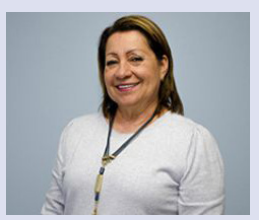

Abdelnour- Esquivel, Ana. Agronomist, with MSc in Plant Physiology and Biochemistry and PhD in agricultural production systems. Professor with 35 years of experience in teaching and research in the field of plant physiology, tissue culture, germplasm conservation and characterization.

Cite this article: Agüero-Hernández AL, Rosales-López C, Herrera C, Vargas-Picado A, Muñoz R, Abdelnour-Esquivel A. Hypoglycemic Effect of Kalanchoe pinnata (Lam) Pers. Leaf Extract. Pharmacogn J. 2020;12(3):557-61. 